\title{
Social transformation and the individual: opportunities and limitations.
}

Abstract: German poet Rilke observed that 'life is lived in transformation' but that 'the only journey is the one within'. These reflections on the everyday, lived experience of change, mobility and identity (trans)formation offer an interesting counterpoint to Stephen Castles' meso and macro level analyses of migration and social transformation. Using data from life narrative interviews, this paper seeks to understand the relationship between identity formation and mobility, through the lens of some of the theoretical and conceptual frameworks identified in Castles' highly influential body of work. It asks to what extent the nation-state represents the limit to the parameters of identity formation, how such limitations are generated and perpetuated, and what are the prospects for future identity transformations.

I begin this paper, which seeks to engage with Stephen Castles' macro and meso level theorising about migration and social transformation, with a somewhat unorthodox approach - snapshots of the lives of four Australians.

Meet Kiet, from Thailand. He is a patriot, although he knows he'll never be treated as an Australian: 'I think that it doesn't matter how much I try, how much I try to be Australian, I will never be accepted as Australian... [they say] "You don't look Australian. You don't look Australian"'. He feels Australian. Kiet likes Australia because it 'gives everybody a fair go. Play everything by the rules' and people are generous.. In his life narrative Kiet identifies a number of significant changes. Raised in a small village in Thailand, he says 'my world was so small'. He first saw a white man in a magazine, when he was 6 years old. Life changed when the Americans built airbases and brought their 'food music movies and way of life'. As a child he 'always wanted to go to America'. Kiet moved to Australia in 1988, after having worked in a number of countries, including Saudi Arabia. He doesn't like Muslims, who are 'too fanatical'. Kiet underwent a life-changing transformation when he migrated to Australia, broke up with his girlfriend, and started gambling. He says he had 'no prospects'. He began to read Buddhist scripture, which caused an emotional breakdown, as he realised this was what he was searching for all life. Since then, his Buddhist beliefs have kept him on the straight and narrow. Kiet is very grateful to Australia, where he thinks all that is 'good is because of Anglo-Saxons', not 'Chinese, Aborigines, Indians' or others. Migrants should 'go with the flow', he says, and he is critical of migrant groups becoming 'dominant'. Kiet feels hurt that people do not value citizenship here. He thinks 'more and more' people will come to Australia, because 'we have very good everything', 'we have a very good gene pool'. Reflecting the sentiment, and indeed the words, of a recent Prime Minister, Kiet wants to limit migration: 'So for me, it's how and what kind of people you want to come. You can set that rule. At what circumstance that you want that people to come. So you can set the bar and we can choose.'

Meet Sandy and Sharla, a mother and daughter in their 60s and 40s respectively, best characterised as working class Anglo-Australians. Sharla travelled a bit when younger, to Bali, around the Pacific, and Europe. Her main identity is as a mother of four children. She is very sporting; and leads what she sees as a standard Australia life - barbecues, catching up with friends, taking kids to sports, scrapbooking: 'So yeah, nah, pretty boring really.' Sharla doesn't watch the news or read newspapers. She is not 'into' politics, seeing it as 'too much arguing', 'it's all negativity'. She feels 'like Australia's sort of getting pushed into a corner'. When asked 'how do you feel about ... people 
of different cultures living in Australia?' Sharla says 'Oh look, you know, it doesn't bother me. I'm quite happy that they're here. But ... I don't know ... I don't agree with them coming over and ... you know, [ ] the government giving them stuff... we have to work hard for what we've got, [ ] So ... yeah but, you know, I'm quite happy to have a ... multicultural country you know, it's good to have all different ... you know, nationalities and stuff around.' She has issues with refugees: 'I'm quite happy with immigration and stuff like that. I suppose what really gets my goat up is you have these refugees coming over ... on the boats, who then walk in or they're on their camp or whatever, and then they get everything given to them right there and then. And then you've got people like us who have worked hard all our lives and you know, like I'm waiting for a house through HomesWest [public housing] and I've gotta wait seven years. But ... knock on the door and there's your house to them, straight away. Like, stuff like that really makes me mad, like if we've gotta wait ... well then they should have to wait.' 'Yeah, and I do feel sorry for them, I feel like their country, like it's horrible where they are and stuff like that, but yeah don't come over and take take take.' She says they come because our government 'give give give'. Sharla loves Australia but realises it is partly because she has not lived elsewhere. Travelling overseas opened her eyes to 'how lucky we are'. She likes Australia Day: 'I suppose if I had a pole out the front l'd chuck a flag on it.' Sharla is nostalgic for the times of her childhood, Australia of the 1970s - the corner deli, the freedom to play, the lower cost of living, no parking problems, returning cool drink bottles for change, and so on. When asked about the prospect of a borderless world, she responds with fears of chaos, people running amuck, and terrorists. She thinks it's a 'crazy' idea. Sharla was married to a third generation Italian, and made some observations about cultural differences, noting that 'even though they're like here in Australia they just definitely keep their ways and ... yeah. It's really funny. [ ] I respect that that's the way they are and ... that's the way they celebrate or whatnot that's their religion or whatever. But I think they also need to learn to ... be part of Australia, you know of us as well'. She sees other cultures (Italians, Portuguese, Croatians) as 'very dominating'. Her life was transformed by her divorce, which caused her economic precarity. Sharla and her children live with her mother, Sandy, while waiting for public housing.

Sandy, Sharla's mum, had a traditional working class upbringing. Her father was a dock worker, her mother stayed at home raising the children. Sandy left school at 14 and worked for 'Tom the Cheap' grocers: 'I've worked hard all me life'. She says children don't appreciate things nowadays. Her husband was a war veteran dealing with his demons through alcohol. Sandy's hobby is to travel. Her house is full of Balinese paraphernalia - artefacts from her travels, paintings, knick knacks, baskets, batik. She goes to Bali three times a year, and has done so since her first transformative trip some years ago, after her husband died. Now she travels regularly to Bali, Vietnam, China, Thailand and Tasmania, 'touristing' and 'vegging'. She says 'nine out of ten people over there are loveable', and if you respect them, they respect you. She sees Australians as 'lucky', in comparison. About migrants she is generally positive, but with reservations about asylum seekers: 'I think if they come out the right way, you know, there's no easy way. Come in with boats and everything, we can't just go over there, you know? Saying that, again, there is a lot of Aussies that live in Bali. [ ] Well unfortunatelyor fortunately-they can't do that here.' Like Sharla, she has misconceptions about the resources available to migrants: 'It's not fair that these migrants that come in, that think that they can just come in. But there are, again, you get a little bit bitter when they can get housing and yet you're born and bred here, and you can't get housing. And for our kids to get the dole or anything like that, they have to go through the third degree and show that they're going for work and that. Well, why 
should they just get handouts?' Yet Sandy thinks migrants work harder than 'us', and would like asylum seekers to be released from detention to work, and not left 'in limbo'. Sandy works for a Vietnamese family: 'you know, they're so polite and they ... every day when you leave work, they say, "thank you. Thank you Sandy, thank you". And [ ] I've never worked for an Aussie that has said, "Thank you for your job. Thank you for your day's work".' Sandy's knee-jerk reaction to the idea of a world without borders is negative: 'realistically, we do have to have borders', but her ambivalence and sense of the incongruities in border policies emerge, and she ultimately also talks herself round to the pointlessness of borders and trying to keep people out.

Meet Jodha, a recent migrant from India. She did her schooling in a (comparatively) small town in Andra Pradesh, and had never travelled outside of this district before moving to Australia two years ago with her husband, who wanted to gain international experience as a mechanical engineer. She chose to live close to a 'cousin brother' in a southern suburb of Perth. She researched the city, and Australia: 'When I googled about Australia I have come to know it's a very peaceful city and people are good and pleasant and beautiful country. Um everything [ ], I got much positive in this. If I had chosen UK or US it would be so busy city, never sleeping city. Life would be very uncomfortable.' Her husband found work quickly: 'it's been very easy, because [ ] within 15 days he got a job,'. But not as a mechanical engineer, 'that's the only problem'. Jodha has a young daughter at school, and is worried about her losing her language, but loves the education system here. The most transformative experience in Jodha's life, according to her, was embracing Christianity. Despite being raised in a Christian family, she was not an active believer until she became ill with an unknown debilitating illness. She says God answered (and continues to answer) her prayers. Jodha sees herself subtly changing as a result of migrating - she is becoming more outgoing. Jodha sees people as 'progressive minded', 'Yeah though, I'm a dark skin, people never, never....do something, they never act like uh, because some people don't like dark skin people'. She believes that if one is positive one will not encounter racism, and she looks forward optimistically to her life in Australia. She is proud of Australia Day, and Australian multiculturalism, but also loves India and her own culture, and expects her child to grow up with those values. Jodha is concerned asylum seekers might be terrorists, asking 'how can you trust them', but also relays the story of her husband working with someone who came as an asylum seeker, and his more sympathetic attitudes. Jodha is a firm believer in nation-states, and that countries need borders for security reasons.

Rainer Maria Rilke, a poet and novelist from the late $19^{\text {th }}$ early $20^{\text {th }}$ centuries, said 'Life is lived in transformation', but also observed that 'The only journey is the one within'. I came across the first quote while reading Amitav Ghosh's The Hungry Tide. It is a book about the sorts of topics on which this journal is focussed - transformation and mobility, cross cultural engagement, race, transnationalism, migrant return, refugees, the search for physical and emotional 'place', and resilience in the face of geographic and political precarity. It provides a sense of the lived experience of mobility, both elite 'northern' mobilities, and precarious, constrained, forced 'southern' mobilities, and the sorts of personal and societal transformations such mobilities generate.

So the poet Rilke, the novelist Ghosh, and renowned sociologist Stephen Castles - all fascinated by journeys and transformation. The notion of journeying within, of personal transformation as being fundamental to the 'lived life', is a productive way of engaging with Castles' work, although it is not an approach he would necessarily use. While Castles tends to take a bird's eye view of global migration, offering key meso and macro level insights into migration patterns and related social, 
economic, political and cultural transformations, the focus of my work has tended to be qualitative and focussed at the micro level, investigating discourses around identity, belonging, nationalism and racism. Castles' work also tends to be comparative, whereas mine has focussed on Australia (indeed, the accusation of 'methodological nationalism' (Beck, 2007) is appropriate). So in this paper I seek to use Castles' insights to inform understandings of the lived experience of transformation, based on the four case studies of people living in Australia. If life is lived in transformation, generating journeys within, how does this occur, how is it talked about, how is transformation understood by the common person, and how do the trends Castles identified play out in the everyday lives of individuals, transforming them and their opportunities?

\section{Studying lives}

The paper opened with four snapshots of lives being lived in transformation. These summaries are a selection taken from a data set of 35 life narrative interviews, part of a larger project using a range of methods to investigate the extent to which Australians have moved beyond national identities to embrace postnational or cosmopolitan orientations to self and other. ${ }^{1}$ These particular cases were not remarkable, but represent common experiences and reflections. The interviews focussed on identity, and its relationship with mobility, and while participants were not asked directly about their experiences of transformation, many talked about personal or societal change as part of their stories.

Before proceeding, there are three methodological issues that require consideration. One is the question of whether it is legitimate to apply theories explaining phenomena at the macro level to the micro level. The second is what status to give interview data. And the third is around issues of sampling, selection and generalisability.

These questions are connected, and will be dealt with together. As a social scientist it is important to avoid the methodological fallacy of scale, for example attempting to apply Castles' macro/meso level observations and theories directly at the micro level. Yet it is also appropriate to investigate how these trends are lived out in ordinary lives, in different contexts. Thus rather than a simply deductive or inductive approach, it is valuable to take an abductive orientation (Dubois and Gadde, 2002) whereby theory is tested against empirical data and empirical data informs theory.

One of the dilemmas faced when studying social reality is what status to give different forms of data. At the macro and meso levels, quantitative data is best as it provides population-level, generalisable results. However, it is blunt, unable to offer the depth, detail and nuance of qualitative data. But qualitative data, often collected face to face through interviews, focus groups, and ethnographic approaches, while full of depth, is necessarily subjective and contextual, and, importantly for analysis, has the limitation of filtering, i.e. there is always a degree of rhetoric and impression management in participants' articulations of their experiences and attitudes (Silverman, 2011). Identity is social, i.e. it is constructed in interaction with others, and in talk (Benwell and Stokoe, 2006). Therefore, exploring personal narratives of transformation generates a number of problems. Talk about changes in one's life often has a rhetorical aspect - it is played up or down in conversation, depending on the how one is presenting one's experiences and agency. This has been

\footnotetext{
${ }^{1}$ Australian Research Council Future Fellowship XXX
} 
identified as a feature of personal narratives. Then there is the necessity of telling a positive story of movement (where one is the agent of change), again a feature of the social desirability effect in personal story-telling. The fluidity of identity, which changes according to context, also makes transformation talk difficult to interpret. And finally change may be invisible (one may not be cognizant of change - being immersed in it may mean it is not 'seen'). These factors are all apparent in Rosenthal's study of former members of Hitler youth (2004). His focus has been on the ways in which life narratives offer accounts that seek to represent the speaker in a positive light, but also how any narration is contingent and contextual: "the presentation of past events is constituted by the present of narrating. The present of the biographer determines the perspective on the past and produces a specific past at times." (Rosenthal, 2004:50). Thus these factors confound the presumption of the interview as a transparent lens into individuals' lived experiences, attitudes and identities. These caveats aside, the narratives outlined offer insights into transformation that is selfidentified, and transformation from an etic perspective.

In terms of a rationale for drawing from just a few examples, there are a number, some pragmatic, and some theoretical. Pragmatically, limitations of space mean achieving a sense of depth for a range of participants is difficult. Thus a decision has been taken to focus on just four characters or cases. More theoretically, ethnomethodologists use Harvey Sacks's argument that the social world reflects 'order at all points'. Thus the study of a single case may elucidate broader (if not universal) patterns. Ethnographers also often use single cases, and in medicine, $\mathrm{N}=1$ studies have become popular. Rosenthal points out that one of the foundational documents for migration research, The Polish Peasant in Europe and America by Thomas and Znaniecki (1918-20; 1958) used a single case study, a biography of a Polish migrant. They argued that 'social science cannot remain on the surface of social becoming, ... but must reach the actual human experiences and attitudes which constitute the full, live and active social reality beneath the formal organization of social institutions' (1958: II, 1834). Indeed Stake has argued that 'case studies will often be the preferred method of research because they may be epistemologically in harmony with the reader's experience and thus to that person a natural basis for generalization' (Stake, 1978: 5).

In Castles' latest edited collection, in which he 'sought to understand the social effects of globalization in nations, neighbourhoods, metropoles and villages' (2015: 3), he argues that to get at glocalisation, translocality, and a global sense of place, researchers must reinstate people as 'spatially situated subjects'. A multiscalar methodology is therefore necessary for the study of migration-related phenomena, focussing both on the macro and micro levels. In the same volume, Rebecca Williamson argues that a multi-scalar approach, 'attempts to unsettle ontological assumptions about the different scales at which migration and processes of transformation are meaningful' (2015:28). In this paper I seek to investigate how Castles' insights about transformation at the macro are experienced and articulated by ordinary folk.

The argument here, therefore, is that if, as Castles argues, transformation is occurring universally (if differentially), then it should be observable in any given individual's life. This is why four cases have been selected from the larger data set, more or less randomly, to explore how the patterns Castles has identified play out in individual lives of migrants and non-migrants. If we want to understand the lived experience of the sorts of forces Castles analyses, the case study may be the way to do it. 
The glimpses above of just four of the participants in the life narratives study demonstrate the complexity of these experiences and identities. We see a Thai background Buddhist who is antirefugee and anti-Muslim, and pro white Australians; an older mainstream Australian, employed by migrants and a committed traveller, embracing cultural diversity in a way her adult daughter, who feels the material threat of competition from migrants/refugees (real or imagined - the misconception that asylum seekers are provided housing, which her mother shares, is simply untrue), does not; and a Christian Indian-background professional migrant spouse who loves Australia and looks forward to a limited assimilation on her own terms.

The examples selected do embody the sorts of transformations wrought by mobility. However it was not only those experiences related to migration that were seen as transformational by participants, or appear to the observer as having been transformational. Across the data participants identified a range of sources for personal transformations. For instance, across the wider set of life narratives, some identified religion as a key turning point in their lives (as demonstrated - the Thai migrant who turned his life around by self-(re?)conversion to Buddhism; the young woman who overcame severe illness in India through Christianity); meeting (or in Sandy's case, losing) a partner opening up horizons and attitudes; war (resulting in a husband's alcoholism; an officer's liberalisation; and in Kiet's case, his first impressions of the West on US bases in Thailand); experiences of parents' divorce, and other self-identified psychological traumas; and so on. ${ }^{2}$ But for many it was movement (whether their own, or others', whether permanent or temporary) that was transformational, often producing one or more of three reactions - a love of, and appreciation for, Australia, often in addition to the love of one's country of origin, regardless of whether one felt one was accepted as an Australian; a growth in openness to diversity, and a desire to appreciate difference - attributes of the cosmopolitan; or a sense of threat and thwarted opportunity resulting from the movements of others.

Before looking at these transformations in relation to Castles' theories, it is important to provide some background to the Australian socio-political context.

\section{The Australian context}

Australia as a nation was built upon the White Australia Policy, legislation and practices that excluded non-whites from migrating, since Federation (1901) until the early 1970s. There followed several decades where multiculturalism was the key policy platform both regulating migration and settlement. This meant that Australians came to pride themselves on being part of a multicultural nation of migrants from diverse racial and cultural backgrounds, partly perhaps, as a way of assuaging the guilt of having dispossessed the indigenous people. Multiculturalism became, to an extent, part of the national identity (Jupp, 2007; Joppke, 2004; Castles et al, 1992; Brett and Moran, 2011). It has been argued that a strong sense of nationalism acted to support the development of this multicultural identity, with the nation offering a political structure and level of stability that enabled positive engagements with difference (Moran, 2011; Brett and Moran, 2011). However,

\footnotetext{
${ }^{2}$ Others focussed on identity categories completely unrelated to nations or ethnicities, such as becoming a Goth, or recognising their homosexuality, as key transformational experiences. Thus particular subjectivities were complex, reflexive, and not necessarily oriented to mobility or the nation, or to transformation, for that matter.
} 
since the late 1990s multiculturalism has been the target of criticism for its inability to ensure social cohesion (Jupp, 2007; Joppke, 20004; Ho, 2013). A key argument in the debate has been around the immigration of people likely to assimilate, captured in the statement of former Prime Minister John Howard 'We are as you all know in a new and dangerous part of the world's history. ... (National security is also) about this nation saying to the world we are a generous open hearted people, ... we have a proud record of welcoming people from 140 different nations. But we will decide who comes to this country and the circumstances in which they come.' (Howard, 2001).

\section{Another great transformation?}

We are living in what seems like a time of unprecedented mobility and transformation. On the internet one can find a short animated image of the major airline flight routes around the world. It shows a minute and a half animation in real time of the myriad connections around the globe, demonstrating vividly that it is a small world, after all. Such images suggest that movement is ubiquitous. Yet Hein de Haas (Czaika and de Haas, 2014), a close colleague of Castles, has demonstrated that in fact global movement has not increased in the last 60 years (the figure of $3 \%$ of the world's population living outside their country of birth has remained stable for many years, and has even fallen slightly). He and Czaika argue that 'Migration has globalized from a destination country perspective but hardly from an origin country perspective, with migrants from an increasingly diverse array of non-European-origin countries concentrating in a shrinking pool of prime destination countries' (2014:283). The difference is that this movement is now less easily controlled, and is more obvious, because rather than global north to global north, south to south, and north to south, we now have significant growth in global south to north movements, and, despite attempts to control mobility on the basis of neoliberal economic imperatives, this movement sometimes appears out of control. Thus, the movements create greater contact with people more culturally and visibly different from ourselves, and the movement is not necessarily on the terms of those nations which have for so long controlled mobility. As a result, movement itself is more visible, and is seen as somewhat threatening. ${ }^{3}$ It is also occurring at a different temporal scale, as Shanthi Robertson (2015) has pointed out, with more short-term migrations and transnational engagements, rather than long-term unidirectional movement with assumed assimilative outcomes. This gives the impression of rapid, widespread mobility, and constant flux. Finally, it is the uneven distribution of migrants in certain countries and in cities that has led to the perception of a step-wise change.

So what is prompting this change and what are its effects? Castles has argued against attempts to develop a single theory of migration, noting the tendency of theories to fragment on the basis of spatial or functional criteria (Castles, 2010). He argues social scientists must stop seeing migration as 'distinct from broader social relationships and change processes' (2010: 1566), arguing against Portes' conclusion that migration does not generally change the fundamental structures and institutions of developed societies. Castles sees migration as one part of the process of transformation of structures and institutions, arguing it can completely reconfigure material, social and economic life, as it has in recent developments in South Korea where the physical location of

\footnotetext{
${ }^{3}$ Castles (2010) is in fact critical of the 'only 3\% of the population' argument, noting it ignores internal movements, and the fact that some countries and urban areas, in particular, have much higher rates.
} 
industry, the need for workers, and the social structures necessary to maintain workers and their families have changed South Korea's geographical, social and economic landscape (Castles, 2017).

Due to the complexity, diversity and importance of context in migration studies, trying to develop a single theory to encompass the range of characteristics of the current state of mobilities is impossible. Castles prefers middle range theory that recognizes structural forces pushing and pulling migrants, individual motivations, and social and economic structures that connect out- and inmigration. His attempt at such a mid-level theory is his social transformation framework. He defines social transformation as 'a fundamental shift in the way society is organised that goes beyond the continual processes of incremental social change that are always at work. This implies a 'stepchange' in which all existing social patterns are questioned and many are reconfigured. Social transformations are closely linked to major shifts in dominant economic, political and strategic relationships.' (Castles, 2010:1576). Elsewhere he sees social transformation as 'a shift in social relationships so profound that it affects virtually all forms of social interaction, and all individuals and communities simultaneously. It [ ] goes beyond the normal processes of change that are always at work' (Castles et al, 2015: 4). Such transformations involve not only technology, the economy (and Castles focus' has often been on the effects of neoliberalism) or military power, but also transformations in culture, social relationships, social institutions, personal and community identities, ideologies and politics. Taking the lead from Polanyi, Castles sees the process of accelerated economic globalisation and the reshaping of economic and military power relations since the end of the Cold War as a new 'great transformation', the effects of which are seen in both the developed and developing world. But he argues the transformation must be studied at the levels of both structure and agency. Using Polanyi's notion of the 'double movement', Castle's argues for the importance of analysing processes of economic globalisation within their particular societal contexts (recognising local historical and cultural configurations), and from the point of view of the individual actors, to understand the transformation of social relationships and identities and the embracing and resistance enacted through individual agency. It is this focus I wish to take.

In the Youtube animation described above, an interesting feature is that the nation-state, the entity that seeks to control and limit movement, and that is at the basis of our conceptualisations of identity, and is the default for social scientists' studies, is missing (Beck, 2007). This image of movement and globalization is in stark contrast to the reality of nation state border control regimes. The material hardware of these regimes was demonstrated in a powerful keynote given by Stephen Castles at the 2007 Australian Sociological Association conference. His talk was accompanied by dozens of slides of barriers - walls, fences, fortifications, check-points - between nation-states globally, barriers the express purpose of which is to limit mobility. In the decade since, these limits to movement have only increased. The implication of the global flight animation image is that movement is ubiquitous, open, and in a sense generic. Such images give little sense of the different types of movement, the motivations and structural impetus' (or barriers), or of the agency involved in such movements.

\section{Transformation at the micro level}

So how has mobility impacted the lives of sandy, Sharla, Jodhu and Kiet, according to their life narratives, and examined through the lens of the key trends Castles has identified? 
Castles suggests that migration, which has always been a normal part of life throughout history, is now characterised by six transformative features (1) globalization of migration flows; (2) acceleration of migration numbers; (3) differentiation of migration types; (4) feminization of migration, (5) growing politicization of migration issues, and (6) proliferation of migration transition (Castles and Miller, 2009:10-12). I want to engage these (apart from the final one, as the life narratives selected do not illustrate this trend), together with the theoretical principles Castles has derived from his most recent project, the STIM project (2015: 10-14). Castles identifies a range of themes from his study of migration trends across the key countries of Australia, South Korea, Mexico and Turkey. These include both observations about social transformation processes associated with migration, and commentary on the current state of migration studies. He identifies the multidirectional process of social transformation such that migration is neither cause nor effect but an integral part of the transformation process; the need to connect migration studies with social theory more generally; the connections between macro-social structure and individual agency, as evidenced in actions and perceptions, influencing the migratory processes and migrants' reception; the role national cultures and histories have in shaping the impact of global influences; and the related recognition that global changes are experienced locally; and finally a call for multimethods and multi-scalar approaches to understanding globalization, since global, national and local dimensions are complexly related.

So let us consider the lives of our four protagonists through the lens of these trends and observations.

\section{Globalization}

Globalization is inevitably multidirectional, with economic forces encouraging movement but also blocking it; with structure and agency often working in concert but sometimes antagonistically; and, as noted, with global, national and local dimensions manifesting and interacting with each other in complex ways. These global changes are experienced locally, and are embraced by some, resisted by others. In the case studies we see mobility for economic (work) and personal (tourism) reasons from culturally and geographically distant regions and where visible difference is salient; the transportation of ideologies, such as religion, from one region to another (Christianity, Buddhism); the embracing, and rejection, of cultural difference; and travel for tourism accompanied by the cosmopolitan consumption of goods and cultural experiences. For some, Sharla in particular, but also the others to some extent, we see a perception of threat and competition from others, due to globalization processes. Economic impetus, and economic threat, are evident in the examples above, reinforcing the value of Castles use of a political economy approach to understand globalization and the causes and effects of mobility We see evidence of the fear generated by growing levels of internal diversity, and a related perception of economic threat/competition from migrants, partly the result of the unequal distribution of economic benefits (and costs) of neoliberal globalization.

\section{Acceleration}

This fear is partly articulated as a product of perceived acceleration, both in terms of a sense of 'flooding' of migrant inflows, but also as a desire to return to a simpler, slower time (Sharla). For others, however, the rapid and massive changes are embraced (Sharla's mother Sandy; Jodha; Kiet). Accelerated globalization can be seen in the transnationalism associated with the Indian family who 
migrated in order to 'gain international experience', without necessarily planning to stay; and the serial tourism of the working class Australian Sandy - travelling to another country at least three times a year illustrates extraordinary acceleration. None of the case studies selected demonstrates the phenomenon of temporary migration, but this relatively recent change to Australia's migration regime is another example of the transformation Castles has identified (see Robertson, 2015).

Differentiation

Differentiation of migration types, such as temporary migration, spousal migration, and the range of employment related migrations, are to be found in the Australian context, but we can also see differentiation in terms of access to mobility and the opportunities it can provide. The examples selected do not illustrate the barriers experienced by many in terms of access to Australia, for example for those seeking asylum, and many of those from culturally and racially distant countries (but see Fozdar, 2017a). However these case studies demonstrate a range of different reactions to mobility, as well as the different opportunities available based on class position. Jodha, for example, was able to migrate due to her class position and the education of her husband, millions of other Indians could not; Sharla feels the economic threat posed by migration because of her precarious position as a low skilled single mother. The class specificity of opportunities to be mobile, and of the impacts of mobility on the existing population is clear. Opportunities and impacts are clearly limited by the social and cultural capital (Bourdieu and Wacquant, 1992) available to each individual.

Feminization

Castles notes that the social transformations associated with new migration regimes have differential effects based on gender. Three of the four case studies selected are of women affected by mobility and whose opportunities have been fundamentally linked to their husbands (Sandy travelling after her husband passed away; Sharla's housing precarity associated with her divorce; and Jodha's migration), illustrating the important role gender plays in mobility. Castles' point is that while traditionally it has been men who have tended to migrate, mobility is increasingly feminized, with the internationalisation of care work, marriage migration and so on.

\section{Politicization}

Finally, the ways in which migration has become politicised is obvious in the negative responses of some of the participants to particular types of migration, with concerns about the links between asylum seekers and terrorism, and fears of Muslims, reflecting political rhetoric since 9/11 (Jupp, 2007). The parallels in the phrasing of former Prime Minister John Howard and the participant Kiet are a starkly tangible case in point. We see in the arguments of Sandy, Sharla, Kiet and Jodha the effects of misinformation, political dog whistling, and the association of terrorism with border crossings. Migration is seen, to some extent by all these participants, as a "problem that needs to be fixed" (Castles, 2010:1567, italics original). Clearly evident are the changing models of citizenship and belonging tracked by Castles (2010), demonstrating how the political environment around immigration has changed significantly in recent decades, from policies of assimilation, to policies of multiculturalism, to the widespread retreat from multiculturalism (Ho, 2013; Joppke, 2004; Hage, 1998). Traces of each are found in the life narratives, identity and attitudes of the participants. As noted, in Australia a sense of multicultural identity developed as a unique aspect of many Australians' self-concept, but, since the late 1990s Australia has returned to the policies and rhetoric 
of assimilation, part of a global trend. Discourses of social cohesion grounded in social and cultural capital, and the argument that diversity endangers solidarity, are popular, and evidenced in the concerns voiced in several of the narratives above (concerns about migrants 'take take taking' and not assimilating; concerns about asylum seekers and Muslims). The 'quiet' of the Australian political landscape that Castles and colleagues noted in their classic Mistaken Identity (Castles, Kalantzis and Morrissey, 1992) has been broken by shrill calls for the need to limit immigration and demands that migrants and ethnic communities generally adopt 'Australian values'. Yet pride in multiculturalism remains, and all participants are seen prefacing any criticism of migrants with statements like Sandy's 'I'm quite happy that they're here. But ...' and 'I'm quite happy to have a ... multicultural country you know, it's good to have all different ... [ ] nationalities and stuff around.' 'I'm quite happy with immigration and stuff like that. I suppose what really gets my goat up is...'. The structure of these statements suggests that positivity about cultural diversity is normative, at least to some extent, causing people to feel the need to hedge their responses in this way, demonstrating that there has been a degree of change in attitudes towards diversity, with a limited level of acceptance of diversity (Brett and Moran, 2011) so long as it is on the white majority's terms (Hage, 1998).

Cosmopolitanization?

I wish to consider a further dimension of the current character of the social transformation associated with contemporary mobility processes. The concept of cosmopolitanism has received much academic interest in the last two decades (Beck, 2007; Kendall, Wodward and Skrbis, 2009; Inglis, 2014). A simple definition focussing on everyday manifestations of cosmopolitanism sees it as a form of postnationalism:

"...cosmopolitanism is generally conceptualized in terms of allegiance to the world community of humankind and almost always defined in contrast to nationalism, because national boundaries remain the chief mechanism for separating 'us' from 'them', and for hierarchizing various people along some kind of moral scale. (Lamont \& Aksartova 2002:2)

Castles tends to be cynical about cosmopolitanism, joining Calhoun (2007) and others in seeing it as a somewhat utopian and elitist vision based on a privileged perspective of the elites of the global north. However some research suggests that 'working class' and global south cosmopolitanism exists (Lamont and Aksartova, 2002; Werbner, 1999). In Australian work, Brett and Moran (2011), and Skrbis and Woodward (2007), have noted the ways in which Australian cosmopolitanism is somewhat limited and with a nationalist edge, and Wise and Velayutham (2009) have examined similar empirical engagements through the lens of everyday multiculturalism. It has been argued by these authors that Australian-ness is an important foundation for positive orientations to difference.

Among the participants in the current study, it is clear that personal transformation involved, for some, becoming more cosmopolitan in outlook as a result of mobility, and, importantly, interpersonal interactions with others who are 'different' and engagements with 'different' cultures. Again, Australian scholars associated with Castles have explored similar effects, including Vince Marotta's work on the Stranger (2016), Wise and Velayutham's collection on 'everyday multiculturalism' (2009), what Vasta (2015) sees as a recognition of 'affinities', and Koleth (2015) calls an ethic of empathy. This effect has been most widely investigated under the 'contact hypothesis', a social psychology theory that suggests the more contact we have with those who are 'different', the lower will be our prejudices. This theory has been demonstrated to be accurate 
through thousands of studies (Allport, 1954; Pettigrew and Tropp, 2006). The way in which Sandy's experience of travels appears to have opened her horizons, the experience of Jodha's husband who works with a refugee - these suggest the potential of such quotidian contact. However, in other cases we do not see such changes - Kiet for example, seems to have adopted the widespread Australian attitude of negativity to certain types of migrant, and an uncritical pride in the nation.

At a more general level, all of the participants are, in some ways, transnational subjects maintaining relationships across distance, being global consumers of experiences and artefacts, or international workers. But in their stories we also see the ubiquity of the nation-state, not so much as a marker of identity but of place, belonging, rights, and exclusion. Kiet's case is perhaps the most interesting - a proud Australian who knows he will never be seen as Australian by others, but maintains his own sense of belonging nonetheless, and who shares many of the positive and negative prejudices about Australia and others (respectively) that the broader mainstream community does. The continuing importance of the nation-state was a constant across the range of methods used in the Fellowship from which this life narrative data is taken. Whether in discussions about whether to buy nationally produced goods, or about global risk, about asylum seekers, Australia's relationship with Asia, about Muslims and 'following the law', or Australia's multicultural policy, whether in constructions of a sense of belonging among UNHCR re-settled refugees, or in arguments about the rights of asylum seekers, and particularly in discussions and survey data about the prospects of a borderless world, the nation-state remains the most important geo-political formation to which participants oriented (Fozdar and Low, 2015; Fozdar and Hartley, 2013; Austin and Fozdar, 2016; Fozdar, 2016, 2017b). Yet, as noted, it also appears that for a minority, the global transformation we are observing, and participating in, is actually one of a growing global consciousness, not just due to an increased recognition of shared risks such as climate change and extremism, but due to mobility and contact. The lives of those of my larger sample who have travelled, living for short or longer periods in countries not of their birth, suggest that perhaps one example of the current 'double movement' is an opening up to difference, even while some are closing down.

\section{Conclusion}

When explored through the lens of everyday lives, the processes Castles has identified can be seen as profound. Two generations ago it would perhaps have been unthinkable to conceive of an elderly white working class Australian admiring and respecting a visibly different migrant employer and seeking out opportunities to engage with difference in Asia, an Indian Christian migrant and a Thai Buddhist Australian being staunch nationalists voicing pride in the achievements of white Australia and distrust of migrants, and a white working class Australian careful to couch criticisms of asylum seekers in positive attitudes towards migrants more generally.

I have tried to demonstrate that from the point of view of the individual, change may not necessarily look like societal transformation and may not be sudden, but rather can be found in a gradual change of perspective, a growing recognition of threat, a creeping sense of nostalgia for a lost past, a developing openness to and valuing of difference. The structural impetus is generally lost in the narrative of a person's life, where agency takes centre stage. Migrants see themselves as having agency, as seen in Jodha's description of her family's choice of Australia as their land of opportunity, where one can get the international experience necessary for workers in today's global economy, 
but such choices are also just about getting on with the job of living, ensuring a good education for one's children, and so on. The social transformation Stephen Castles is interested in, as well as generating changes at the structural level, is producing modified subjectivities - individuals on the cusp of cosmopolitanism. While there remains a great deal of resistance, there are glimpses of a cosmopolitan transformation.

\section{References}

Allport, G. W. (1979). The nature of prejudice. Basic books.

Austin, C., \& Fozdar, F. (2017). "Team Australia": Cartoonists Challenging Exclusionary Nationalist Discourse. Journal of Australian Studies, 41(1), 65-80.

Beck, U. (2007). The cosmopolitan condition: Why methodological nationalism fails. Theory, culture \& society, 24(7-8), 286-290.

B. Benwell and E. Stokoe (2006). Discourse and Identity. Edinburgh, UK: Edinburgh University Press.

Brett, J \& Moran, A. (2011) Cosmopolitan Nationalism: Ordinary People Making Sense of Diversity. Nations and Nationalism, 17 (1): 188-206

Calhoun, C. (2007). Nations matter: Culture, history and the cosmopolitan dream. Routledge.

Castles, S. (2010). Understanding global migration: A social transformation perspective. Journal of ethnic and migration studies, 36(10), 1565-1586.

Castles, S., De Haas, H., \& Miller, M. J. (2013). The age of migration: International population movements in the modern world. Palgrave Macmillan.

Castles, S., Kalantzis, C. \& Morrissey, M. (1992) Mistaken Identity: Multiculturalism and the Demise of Nationalism in Australia. Sydney: Pluto Press.

Castles, S., Ozkul, D., Cubas, M. (2015). Social Transformation and Migration: National and Local Experiences in South Korea, Turkey, Mexico and Australia. Basingstoke, UK: Palgrave Macmillan.

Czaika, M., \& de Haas, H. (2014). The globalization of migration: Has the world become more migratory?. International Migration Review, 48(2), 283-323.

Dubois, A., \& Gadde, L. E. (2002). Systematic combining: an abductive approach to case research. Journal of business research, 55(7), 553-560.

Fozdar, F. (2017a) "It's the end of the world as we know it...and I feel fine": Considering a postnational world. Marotta, $\mathrm{V}$ and Boese, $\mathrm{M}$ (eds) 'Critical Reflections on Migration, 'Race' and Multiculturalism: Australia in a Global Context". Routledge.

Fozdar, F. (2017b). 'No borders'. Journal of Language and Politics, 16(3), 367-387.

Fozdar, F. (2016). Asian invisibility/Asian threat: Australians talking about Asia. Journal of Sociology, 52(4), 789-805.

Fozdar, F., \& Hartley, L. (2013). Civic and ethno belonging among recent refugees to Australia. Journal of refugee studies, 27(1), 126-144.

Fozdar, F., \& Low, M. (2015). 'They have to abide by our laws... and stuff': ethnonationalism masquerading as civic nationalism. Nations and Nationalism, 21(3), 524-543.

Hage, G. (1998) White Nation: Fantasies of White Supremacy in a Multicultural Society. Annandale: Pluto Press Australia.

Ho, C. (2013) 'From social justice to social cohesion: A history of Australian multicultural policy'. In: Jakubowicz, A. \& Ho, C. (Eds.) 'For Those Who've Come Across the Seas': Australian Multicultural Theory, Policy and Practice. North Melbourne: Australian Scholarly Publishing, 31-41. 
Howard, J (2001) Federal Election Campaign Launch Speech, 28th October 2001. Available at https://en.wikiquote.org/wiki/John Howard

Jackman, M. R., \& Crane, M. (1986). "Some of my best friends are black...": Interracial Friendship and Whites' Racial Attitudes. Public Opinion Quarterly, 50(4), 459-486.

Joppke, C. (2004) 'The retreat of multiculturalism in the liberal state: Theory and policy'. The British Journal of Sociology, 55 (2), 237-257.

Jupp, J. (2007) From White Australia to Woomera: The Story of Australian Immigration. Port Melbourne, Victoria: Cambridge University Press.

Kendall, G., Woodward, I., \& Skrbis, Z. (2009). The sociology of cosmopolitanism: Globalization, identity, culture and government. Springer.

Koleth, E. (2015). Multiculturalism at the Margins of Global Sydney: Cacophonous Diversity in Fairfield, Australia. In Social Transformation and Migration (pp. 237-254). Palgrave Macmillan, London.

Lamont, M., \& Aksartova, S. (2002). 'Ordinary cosmopolitanisms: Strategies for bridging racial boundaries among working-class men'. Theory, Culture \& Society, 19(4), 1-25.

Marotta, V. P. (2016). Theories of the Stranger: Debates on Cosmopolitanism, Identity and Crosscultural Encounters (Vol. 119). Taylor \& Francis.

Pettigrew, T. F., \& Tropp, L. R. (2006). A meta-analytic test of intergroup contact theory. Journal of personality and social psychology, 90(5), 751.

Robertson, S 2015, 'The temporalities of international migration: implications for ethnographic research', in S Castles, D Ozkul \& MA Cubas (eds), Social transformation and migration: national and local experiences in South Korea, Turkey, Mexico and Australia, Palgrave Macmillan, Basingstoke, pp. 45-60.

Rosenthal, G. (2004). Biographical research. Qualitative research practice, 48-64.

Silverman, D (2011) Interpreting qualitative data: a guide to the principles of qualitative research. 4th Edition. London; Los Angeles. Sage.

Skrbis, Z., \& Woodward, I. (2007). The ambivalence of ordinary cosmopolitanism: Investigating the limits of cosmopolitan openness. The sociological review, 55(4), 730-747.

Stake, R. E. (1978). The case study method in social inquiry. Educational researcher, 7(2), 5-8.

Vasta, E. (2015). Generations and Change: Affinities Old and New. In Castles et al, Social Transformation and Migration (pp. 283-297). Palgrave Macmillan, London.

Williamson, R. (2015). 'Towards a Multi-scalar Methodology: The Challenges of Studying Social Transformation and International Migratio'n. In Social Transformation and Migration (pp. 17-32). Palgrave Macmillan, London.

Wise, A and Velayutham, S (eds) (2009) Everyday Multiculturalism. London: Palgrave. 